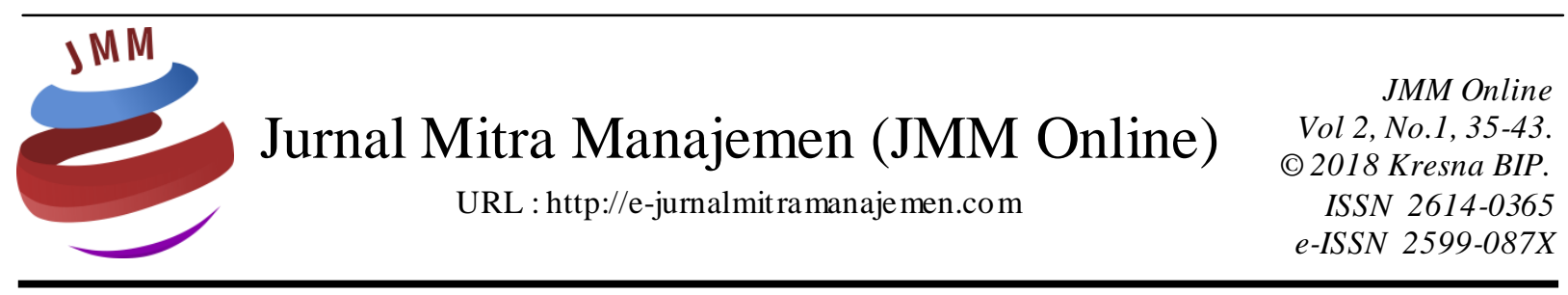

PENGARUH NET PROFIT MARGIN TERHADAP HARGA SAHAM PT. UNILEVER TBK TAHUN 2011-2016

Eko Widarta Utama

Universitas Prof. Dr. hazairin, S.H., Bengkulu

\section{INFORMASI ARTIKEL}

Dikirim : 09 Januari 2018

Revisi pertama :15 Januari 2018

Diterima : 15 Januari 2018

Tersedia online : 23 Januari 2018

Kata Kunci : Pengaruh, Net Profit Margin, Harga Saham

Email : ekowidarta2712@gmail.com

\section{ABSTRAK}

Tujuan penelitian ini adalah untuk mengetahui pengaruh net profit margin terhadap harga saham. Sifat pada penelitian ini adalah penelitian asosiatif yaitu penelitian untuk mengetahui hubungan antar variabel, yang mengungkapkan hubungan antara net profit margin dan harga saham PT Unilever Tbk. Penelitian dilakukan pada awal bulan Desember 2017 hingga akhir bulan Desember 2017. Alat analisa menggunakan regresi linier sederhana. Teknik pengambilan sampel dalam penelitian ini adalah dengan menggunakan purposive sampling. Populasi penelitian ini mencakup semua total laporan tahunan yang sudah diterbitkan PT. Unilever Tbk yaitu empat belas, sementara sampel yang digunakan adalah laporan tahunan PT. Unilever Tbk tahun 2011-2016 yang berjumlah enam.

Penelitian ini menunjukkan hasil bahwa net profit margin tidak berpengaruh terhadap harga saham PT. Unilever Tbk tahun 2011-2016. Selama enam tahun terakhir sejak tahun 2011 sampai 2016, net profit margin mengalami kemerosotan yang konsisten sementara dilain sisi sahamnya justru semakin tinggi serta hasil penelitian yang diperoleh peneliti menunjukkan bahwa setiap kenaikan yang terjadi pada harga saham tidak dipengaruhi oleh net profit margin dan belum dapat dipastikan akan berdampak besar atau berpotensi bagi perubahanperubahan yang ada pada harga saham. 


\section{PENDAHULUAN \\ Latar Belakang}

Pasar modal di Indonesia adalah salah satu tempat yang memiliki sistem yang menghubungkan berbagai investor-investor baik dalam negeri maupun luar negeri yang berguna bisa menambah pendanaan perusahaan, sehingga pasar ini menjadi pasar yang sangat dibutuhkan perusahaan-perusahaan milik pemerintah dan swasta saat ini dan tidak bisa dihindari. Dapat diringkas bahwa pasar ini diperuntukkan untuk mempertemukan antara perusahaan sebagai pihak yang memerlukan penambahan dana dari biaya operasional suatu perusahaan yang begitu besar dan investor sebagai pihak yang ingin berinvestasi pada suatu perusahaan untuk menciptakan keuntungan dimasa depan. Pasar modal bagi suatu negara, manfaatnya tidak hanya dirasakan baik oleh pihak swasta saja, namun juga bisa dirasakan masyarakat ekonomi dan pemerintah, dengan adanya keberadaan dan peran pasar modal di tengah kehidupan ekonomi bangsa dapat ikut menumbuhkan perekonomian.

Suatu perusahaan yang telah menjadi perusahaan publik dapat menggunakan pasar modal sebagai satu dari berbagai sumber modal untuk tambahan dananya. Perusahaan-perusahaan yang telah go public tersebut terus didorongkan untuk dapat lebih meningkatkan kualitas kinerja operasionalnya oleh berbagai pihak, karena sebagian besar publik mengakui bahwa perusahaan yang sudah go public lebih profesional dan kompeten dibandingkan dengan perusaahaan pribadi. Pada satu sisi lainnya tercapainya satu kondisi, bukan hanya membuat dorongan dan motivasi dalam perubahan bentuk kecil atau besar sekalipun bagi perusahaan itu sendiri atau untuk dapat meningkatkan laba saja, akan tetapi turut mempengaruhi emosional dan pemikiran positif seluruh karyawan perusahaan untuk memacu semangat dan loyalitas dalam membangun pertumbuhan perusahan dan memberikan hasil dan kinerja yang terbaik serta lebih baik lagi untuk perusahaannya yang akhirnya berdampak meningkatnya nilai perusahaan secara keseluruhan, karena setiap peningkatan nilai perusahaan akan diikuti dengan kinerja operasional atau aktivitasnya dan kinerja keuangan yang meningkat juga, yang umumnya akan mempunyai dampak terhadap harga saham di bursa saham atau pasar modal. Perbedaan demi perbedaan yang dialami banyak perusahaan pada harga sahamnya di pasar modal tidak terlepas dari beragamnya keinginan dari penanam-penanam modal kepada suatu saham di perusahaan.

Net profit margin yaitu ukuran dasar untuk mengetahui besaran keuntungan perusahaan pada setiap satu periode kegiatan yang sudah dilakukan dari hasil aktifitas perdagangan dan jasa. Nominal yang tertera pada Net Profit Margin setiap perusahaan belum tentu menggeser nominal harga saham untuk beranjak naik maupun turun, karena semua bergantung kondisi dan situasi yang sedang dihadapi oleh suatu perusahaan.

Perkembangan yang terjadi dari beberapa tahun sudah memberikan kontribusi bagi banyak perusahaan untuk menggerakkan bisnisnya dan meningkatkan keuntungan melalui transaksi saham perusahaan bisa memperoleh tenaga untuk membiayai kebutuhan dan perencanaan dalam memajukan usahanya salah satunya melalui saham. Saham sangat bernilai sehingga harganya menjadi beragam, sehingga bisa menjadi terlalu tinggi, terlalu rendah, ataupun normal. Sunariyah (2004: 128) mengatakan 
bahwa harga saham adalah harga selembar saham yang berlaku dalam pasar saat ini di bursa efek. Saham juga sama mengikuti hukum permintaan dan penawaran, pada saat permintaan saham meningkat, maka harga saham tersebut akan cenderung meningkat. Sebaliknya, pada saat banyak orang menjual saham, maka harga saham tersebut cenderung akan mengalami penurunan (Anoraga, 2003: 58). Kekuatan pasarlah yang akan memberikan dampak terhadap harga-harga saham dipasar modal yang setiap waktu bisa mengalami pergerakan dan penuh ketidakpastian.

Perusahaan besar PT. Unilever Tbk merupakan perusahaan yang mempunyai berbagai produk-produk berkualitas dan memiliki catatan perkembangan harga saham yang setiap tahun mengalami peningkatan yang besar dari mulai harga saham ribuan hingga mencapai puluhan ribuan. Sementara untuk nilai net profit margin, perusahaan ini setiap tahun mengalami penurunan, menurut peneliti nominal yang tinggi pada net profit margin belum dipastikan dapat mengubah atau ikut menggeser nominal harga saham suatu perusaahaan, sebaliknya sama juga dengan nominal net profit margin yang rendah.

\section{Rumusan Masalah}

Berdasarkan penjelasan yang berasal dari latar belakang tersebut diatas, penulis mengemukakan rumusan permasalahan yaitu "apakah net profit margin berpengaruh terhadap harga saham PT. Unilever Tbk tahun 2011-2016".

\section{Tujuan Penelitian}

Penelitian ini memiliki tujuan menguji, dan mengembangkan penelitian ini secara lebih jelas dan untuk mengetahui ada tidaknya pengaruh net profit margin terhadap harga saham PT. Unilever Tbk tahun 2011-2016.

\section{Manfaat Penelitian}

Penelitian diharapkan memberikan manfaat untuk:

1. Dapat dijadikan pengetahuan penting bagi masyarakat mengenai kaitan antara net profit margin dengan harga saham PT Unilever Tbk.

2. Dapat dijadikan masukan lebih mendalam bagi banyak peneliti tentang net profit margin terhadap harga saham.

3. Dapat memotivasi peneliti lain agar tertarik untuk mengembangkan serta menyempurnakan penelitian ini dimasa mendatang

\section{KAJIAN PUSTAKA \\ Pasar Modal}

Pada modal dibentuk dalam kegiatan yang berkaitan dengan transaksi perdagangan, sama seperti pasar pada umumnya disana ada kegiatan penjualan dan pembelian efek atau surat berharga karena pasar modal hanya sebagai jembatan penyambung. Pasar modal muncul untuk solusi pembiayaan kegiatan-kegiatan operasional akibat dari kebutuhan dasar perusaahaan yang besar, sehingga bagi perusahaan dana yang diperoleh tersebut dapat sangat membantu dan bermanfaat, juga untuk dalam rangka kebutuhan investasinya. Menurut Keown et al. (2011:11) lokasi untuk saham atau surat-surat berharga dapat diperjualbelikan yaitu di pasar modal. 


\section{Laporan Keuangan}

Kegunaan laporan keuangan sebagai alat pemberi informasi tertulis memang sangat berarti, disana tercatat semua hasil dari pencapaian selama satu periode, rincian besaran biaya-biaya yang dikeluarkan untuk memenuhi kebutuhan operasional dan pendapatan yang dihasilkan melalui kegiatan perusahaan. laporan keuangan bukan hanya sekedar bermanfaat, laporan keuangan juga membantu dalam proses pengambilan sebuah keputusan, dengan informasi tersebut dapat membentuk perhitungan yang tepat mengenai suatu perusahaan, apa yang akan dihadapi dan terjadi di masa depannya, sehingga sangat penting laporan ini bagi perusahaan sendiri dalam menilai pergerakan yang sudah dilakukan dan bagi pihak diluar perusahaan sebagai penyumbang dana dan calon investor. "Laporan keuangan merupakan suatu informasi yang menggambarkan kondisi keuangan suatu perusahaan, dan lebih jauh informasi tersebut dapat dijadikan sebagai gambaran kinerja keuangan perusahaan tersebut" (Fahmi, $2013: 21$ ).

\section{Net Profit Margin}

Net profit margin yang tinggi belum dapat dipastikan meningkatkan harga saham perusahaan, akan tetapi net profit margin yang tinggi secara logis akan mengundang investor untuk bersedia memberikan dana karena net profit margin mendeskripsikan keuntungan yang diperoleh perusahaan, semakin besar laba yang diperoleh suatu perusahaan maka keuntungan yang akan dibagikan juga besar yang kemudian mempengaruhi investor untuk membeli saham perusahaan tersebut, sehingga kejadian ini menggambarkan sebagaimana adanya hukum permintaan dan penawaran. Menurut Benny (2009: 170) net profit margin adalah rasio yang digunakan untuk menunjukkan kemampuan perusahaan dalam menghasilkan keuntungan bersih setelah dipotong pajak.

\section{Harga Saham}

Harga saham di pasar modal berhubungan dengan bagaimana cara suatu perusahaan untuk memperoleh dana dengan menjual atau melakukan penerbitan saham lewat pasar modal. Menurut peneliti ada tiga hal mendasar dari masyarakat sebelum membeli saham suatu perusahaan, yaitu $3 \mathrm{~B}: 1$ ) bagaimana kinerja perusahaan, 2) bagaimana citra perusahaan, 3) bagaimana manajemen perusahaan. Jogiyanto (2008: 143) harga saham adalah harga yang terjadi di pasar bursa pada saat tertentu yang ditentukan oleh pelaku pasar dan ditentukan oleh permintaan dan penawaran saham yang bersangkutan di pasar modal.

\section{Kerangka Konseptual}

Kerangka konseptual secara mendalam berusaha menjelaskan hubungan antara variabel yang akan diteliti. Berdasarkan permasalahan yang sudah dikemukakan diatas, maka peneliti menjelaskan bentuk konseptual sebagai berikut :

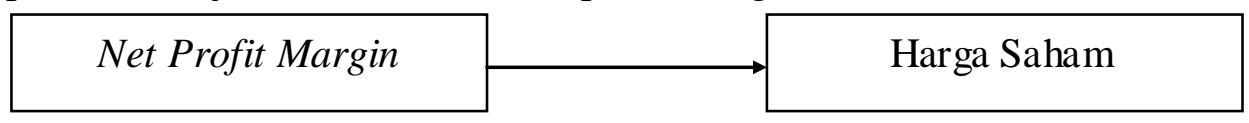

Gambar 1. Kerangka Konseptual 


\section{Hipotesis}

Dari berbagai penjabaran teori dan penjelasan peneliti mengangkat sebuah hipotesis "diduga net profit margin berpengaruh terhadap harga saham PT. Unilever Tbk tahun 2011-2016”.

\section{METODE PENELITIAN}

\section{Sifat Penelitian}

Penelitian ini bersifat penelitian asosiatif. Hasan (2002) menyatakan bahwa model hubungan yang dihubungkan baik dari mulai yang berjumlah variabel satu dengan variabel yang lain yang bermanfaat sebagai gambaran dalam menganalisis adanya hubungan antara variabel yang mempengaruhi atau dipengaruhi.

\section{Jenis dan Sumber Data}

Jenis data dalam penelitian yaitu kuantitatif, kuantitatif adalah penelitian dengan memperoleh data yang berbentuk angka (Sugiyono, 2012: 14). laporan keuangan pada PT Unilever Tbk tahun 2011 - 2016, menjadi data kuantitatif penelitian ini. Sementara untuk sumber datanya adalah sekunder, yaitu data yang didapat tidak secara langsung dari objek penelitian. Peneliti mendapat data yang sudah jadi, yang dikumpulkan oleh pihak lain dengan berbagai cara atau metode pada umumnya. Sumber data yang digunakan berasal dari laporan keuangan PT Unilever Tbk tahun 2011 - 2016, berupa ikhtisar keuangan dan harga saham.

\section{Populasi, Sampel dan Waktu Penelitian}

Populasi tidak berupa orang saja, bisa berupa objek dan berbentuk benda. Populasi dalam penelitian ini mencakup semua total laporan tahunan yang sudah diterbitkan PT. Unilever Tbk berjumlah 14, yaitu mulai dari tahun 2003-2016. Untuk mendukung penelitian yang didasarkan perumusan masalah dan teori yang sudah dijabarkan, sehingga sampel yang dipilih berjumlah 6 atas dasar purposive sampling. Penelitian dilaksanakan pada awal bulan Desember 2017 sampai akhir bulan Desember 2017.

\section{Teknik Pengambilan Sampel}

Metode pengambilan sampel dalam penelitian ini adalah dengan menggunakan purposive sampling, yaitu teknik pengambilan sampel didasarkan pada tujuan tertentu dengan memperhatikan ciri-ciri dan karakteristik populasi (Arikunto, 2010: 134). Kriteria yang dimaksud peneliti adalah memilih data terbaru dari laporan tahunan PT Unilever Tbk mulai tahun 2011-2016 untuk dijadikan sampel.

\section{Teknik Pengumpulan Data}

Teknik pengumpulan data yang digunakan adalah sebagai berikut

a. Metode kepustakaan, adalah mengumpulkan data dan teori melalui berbagai sumber-sumber dan dijabarkan, baik dari jurnal, maupun dari buku-buku yang dibutuhkan peneliti. 
b. Metode dokumentasi, yaitu dengan mengumpulkan data yang dilakukan dengan menganalisis berkas dan dokumen-dokumen keuangan perusahaan berupa laporan keuangan.

\section{Metode Analisa}

\section{Analisis Regresi Linie r Sederhana}

Teknik analisis regresi sederhana diterapkan dalam penelitian ini untuk menguji pengaruh satu variabel independen terhadap variabel dependen yaitu net profit margin (X) dan harga saham (Y). Karena data yang akan diolah berbeda satuan, maka data di ubah ke dalam bentuk Logaritma Natural (LN). Berikut rumus regresi sederhana:

$$
\begin{array}{ll}
\text { Keterangan } & : \\
\mathrm{Y} & \mathrm{LNY}=\mathrm{a}+\mathrm{b}_{1} \mathrm{LNX} \\
\mathrm{LN} & =\text { Larga Saham } \\
\mathrm{a} & =\text { Konstanta } \\
\mathrm{X} & =\text { Net profit margin } \\
\mathrm{b}_{1} & =\text { Koefisien Regresi }
\end{array}
$$

Untuk mencapai dan menunjang tujuan penelitian, maka peneliti melakukan langkah-langkah analisis tertentu. Tahapan yang sudah ditempuh selama penelitian adalah sebagai berikut:

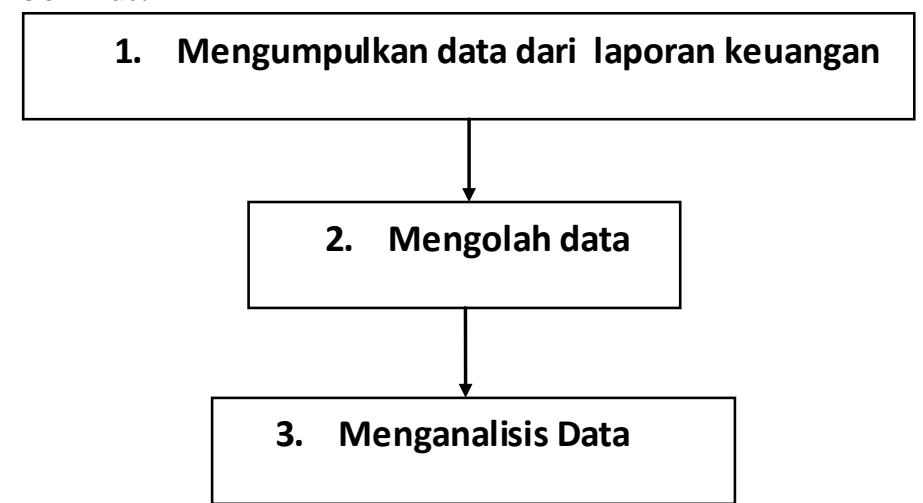

\section{Gambar 2. Proses Analisis Data}

\section{HASIL PENELITIAN DAN PEMBAHASAN}

\section{Hasil Penelitian}

Jejak perkembangan net profit margin dan harga saham pada PT. Unilever Tbk dapat di lihat dibawah ini berdasarkan data laporan tahunan yang diperoleh dari PT. Unilever Tbk sejak tahun 2011-2016. Berikut data net profit margin dan harga saham:

Tabel 1. Net Profit Margin dan Harga Saham

PT. Unilever Tbk. Tahun 2011-2016

\begin{tabular}{|l|l|l|}
\hline Tahun & Net Profit Margin (\%) & Harga Saham (Rp) \\
\hline 2011 & 17,7 & 18.800 \\
\hline 2012 & 17,7 & 20.850 \\
\hline
\end{tabular}


Lanjutan Tabel 1. Net Profit Margin dan Harga Saham PT. Unilever Tbk. Tahun 2011-2016

\begin{tabular}{|l|l|l|}
\hline Tahun & Net Profit Margin (\%) & Harga Saham (Rp) \\
\hline 2013 & 17,4 & 26.000 \\
\hline 2014 & 17,6 & 32.300 \\
\hline 2015 & 16,1 & 37.000 \\
\hline 2016 & 14,9 & 38.800 \\
\hline
\end{tabular}

Sumber : Data Sekunder diolah (2018)

Dari data diatas dapat dijelaskan bahwa terjadi proses penurunan nilai net profit margin dari tahun 2011 sebesar 17,7\% sampai tahun 2016 sebesar 14,9\%, sementara untuk nominal harga saham mengalami kenaikan harga, selisih kenaikan dari tahun 2011 hingga 2016 adalah sebesar Rp 19.200 (Rp 38.000 - Rp $18.800=\operatorname{Rp~19.200).~}$ Berdasarkan data yang dikumpulkan diatas, untuk dapat mengetahui pengaruh net profit margin terhadap harga saham selanjutnya data akan di rubah kedalam bentuk LN (Logaritma Natural) dikarenakan ada perbedaan satuan data.

Tabel 2. LN Net Profit Margin dan Harga Saham PT. Unilever Tbk. Tahun 2011-2016

\begin{tabular}{|c|c|c|}
\hline \multirow{2}{*}{ Tahun } & \multicolumn{2}{|c|}{ LN } \\
\cline { 2 - 3 } & Net Profit Margin & Harga Saham \\
\hline 2011 & $-1,73$ & 9,84 \\
\hline 2012 & $-1,73$ & 9,95 \\
\hline 2013 & $-1,75$ & 10,17 \\
\hline 2014 & $-1,74$ & 10,38 \\
\hline 2015 & $-1,83$ & 10,52 \\
\hline 2016 & $-1,90$ & 10,57 \\
\hline
\end{tabular}

Sumber : Data Sekunder Diolah (2018)

Berdasarkan dari apa yang diperoleh diatas kemudian diolah, sehingga diperoleh hasil dari analisis data yang membentuk persamaan regresi sederhana, yaitu sebagai berikut:

$$
\mathrm{LNY}=4,315-3,327 \mathrm{X}
$$

Berdasarkan hasil yang diperoleh diatas, maka dapat disimpulkan:

1. Konstanta sebesar 4,315 menunjukkan bahwa harga saham akan sama besar konstanta (a) sebesar 4,315 bila variabel net profit margin tidak berubah.

2. Koefisien regresi $X$ sebesar - 3,327 yang menyatakan bahwa setiap penurunan 1 satuan, maka variabel net profit margin akan menurunkan harga saham sebesar 3,327 .

Tabel 3. Hasil Pengaruh Secara Parsial

\begin{tabular}{|ll|l|l|l|l|l|}
\hline \multirow{2}{*}{ Model } & \multicolumn{2}{|l|}{ Unstandardized Coefficients } & $\begin{array}{l}\text { Stand ardized } \\
\text { Coefficients }\end{array}$ & & \multirow{2}{*}{ Sig. } \\
\cline { 2 - 5 } & & B & Std. Error & Beta & & \\
\hline \multirow{2}{*}{1} & (Constant) & 4,315 & 2,386 & & 1,809 &, 145 \\
& LN_NPM & $-3,327$ & 1,339 &,- 779 & $-2,484$ &, 068 \\
\hline
\end{tabular}

Sumber : Hasil Penelitian Diolah (2018) 
Berdasarkan tabel diatas mengenai Uji t maka diperoleh angka signifikan variabel NPM (net profit margin) sebesar 0,068 lebih tinggi dari tingkat kesalahan 0,05 yang menunjukkan tidak signifikan dan $\mathrm{t}$ hitung berada pada $-2,484<\mathrm{t}$ tabel 2,446, maka koefisien regresi NPM (net profit margin) tidak berpengaruh sehingga dapat disimpulkan bahwa variabel NPM (net profit margin) tidak berpengaruh terhadap harga saham secara terpisah atau parsial, Maka $\mathrm{H}_{0}$ diterima dan $\mathrm{H}_{\mathrm{a}}$ ditolak. Hasil ini sama dengan penelitian yang sudah dilakukan oleh Sha (2015) yang menyatakan bahwa "... NPM ... tidak berpengaruh signifikan terhadap harga saham", kemudian penelitian dari Susilo (2014) menyimpulkan “... Net Profit Margin (NPM) tidak berpengaruh pada Harga Saham”. Gambar hipotesis akan ditunjukkan sebagai berikut:

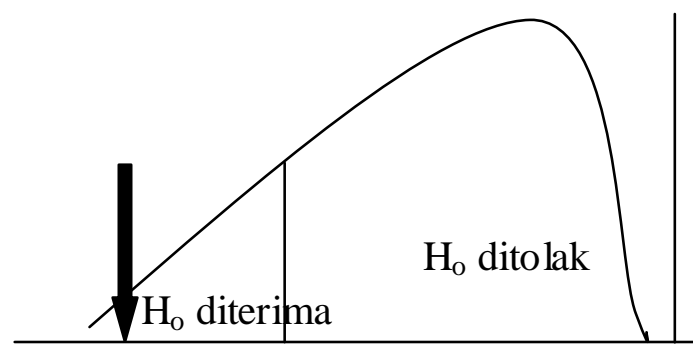

$$
-2,484 \quad 2,446
$$

Gambar III. Keputusan Hipotesis

Sumber: Data Sekunder Diolah (2018)

\section{Pembahasan}

Sebagaimana atas dasar laporan tahunan PT. Unilever Tbk tahun 2011-2016 yang sudah dianalisis dan diolah peneliti, maka peneliti mengemukakan pembahasanpembahasan penting yaitu:

1. Selama enam tahun terakhir sejak tahun 2011 sampai 2016, net profit margin mengalami kemerosotan yang konsisten (dapat dilihat di tabel I), sementara dilain sisi sahamnya justru semakin tinggi.

2. Berdasarkan hasil penelitian yang diperoleh peneliti menunjukkan bahwa setiap kenaikan yang terjadi pada harga saham tidak dipengaruhi oleh net profit margin dan belum dapat dipastikan akan berdampak besar bagi perubahan-perubahan yang ada pada harga saham.

\section{KESIMPULAN DAN SARAN}

\section{Kesimpulan}

Berdasarkan dari hasil pengujian yang sudah dilakukan melalui penelitian ini, maka dinyatakan bahwa net profit margin tidak berpengaruh terhadap harga saham pada PT. Unilever Tbk atau dapat diperjelas, meningkatnya harga saham pada PT. Unilever Tbk tidak dipengaruhi net profit margin. Sehingga berapa pun nilai net profit margin baik tinggi ataupun rendah belum tentu dapat mengubah atau menggeser naik maupun turun untuk nominal harga saham. 


\section{Saran}

Atas dasar hasil penelitian yang diperoleh dan kesimpulan yang ada, maka peneliti memberikan saran dan masukkan sebagai berikut:

1. Walaupun net profit margin tidak berpengaruh terhadap harga saham, net profit margin tetap harus dijaga agar stabil karena net profit margin mendeskripsikan dan memberikan informasi mengenai besaran laba suatu perusahaan.

2. Diharapkan peneliti mendatang yang tertarik mengenai harga saham dan net profit margin agar meneliti perusahan besar lainnya sehingga ada masukan-masukan untuk ilmu pengetahuan dibidang ini.

\section{DAFTAR PUSTAKA}

Anoraga, Pandji dan Piji Pakarti. 2003. Pengantar Pasar Modal Edisi Revisi. Jakarta: PT. Rineka Cipta.

Arikunto, Suharsimi. 2006. Prosedur Penelitian Suatu Pendekatan Praktik. Jakarta: Rineka Cipta.

Fahmi, Irham. 2013. Pengantar Manajemen Keuangan. Cetakan Kedua. Bandung: Alfabeta.

Hasan, M. Iqbal. 2002. Pokok-pokok Metodologi Penelitian dan Aplikasinya. Bogor: Ghalia Indonesia.

Jogiyanto. (2008). Teori Portofolio dan Analisis Investasi. Edisi Ketiga. Yogyakarta: BPFE.

Keown, Arthur J dan John D Martin et al. 2011. Manajemen Keuangan: Prinsip dan Penerapan. Terjemahan oleh Marcus Prihminto Widodo. Jilid 1. Edisi Kesepuluh. Jakarta: PT. Indeks.

Sha, Thio Lie. 2015. Pengaruh Kebijakan Dividen, Likuiditas, Net Profit Margin, Return On Equity, Dan Price To Book Value Terhadap Harga Saham Pada Perusahaan Manufaktur Yang Terdaftar Di Bursa Efek Indonesia 2010-2013. Jurnal Akuntansi/Volume, No. 02, Mei 2015: 276-294.

Sugiyono. 2012. Metode Penelitian Kuantitatif $R \&$ D. Bandung: Alfabeta.

Sunariyah. 2004. Pengantar Pengetahuan Pasar Modal. Edisi Keempat. Yogyakarta: AMP YKPN.

Susilo, Yosua Eko. 2014. Pengaruh ROA, ROE, PER, PBV, NPM, OPM terhadap Harga Saham Perusahaan Perbankan pada Tahun 2008-2011. Jurnal Penelitian Fakultas Ekonomi dan Bisnis Program Studi Akuntansi, Universitas Dian Nuswantoro Semarang. 